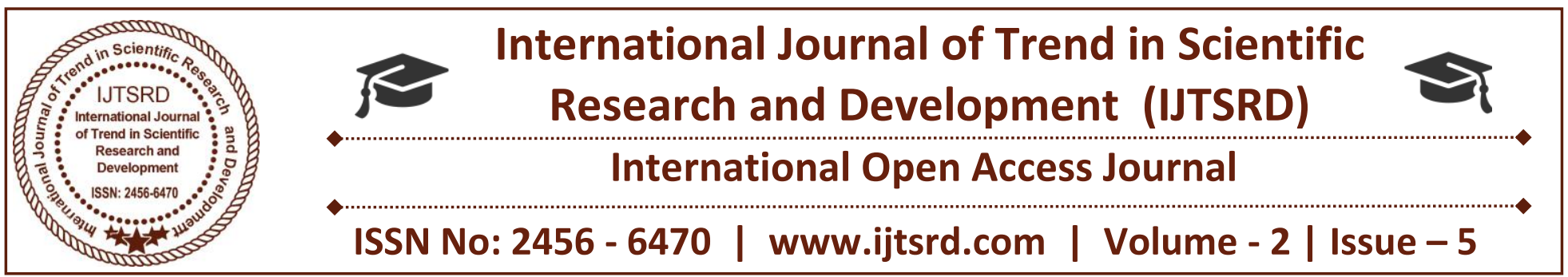

\title{
Managing Aesthetic Labour Through Hr Practices at Hypermarkets in Indian Retail Sector
}

\author{
Ms. M. Pushpa ${ }^{1}$, Dr. Minu Zachariah ${ }^{2}$ \\ ${ }^{1}$ Master of Business Administration, ${ }^{2}$ Assistant Professor \\ Department of Management Studies and Research Centre, \\ BMS College of Engineering, affiliated to VTU, \\ Bull Temple Road, Basavangudi, Bangalore, Karnataka, India
}

\section{ABSTRACT}

The retail industry in India is booming and witnessing huge growth. It provides $8 \%$ employment, accounts over $10 \%$ of the Gross Domestic Product (GDP) of our country. The overall retail market is expected to grow at $12 \%$ per annum providing more employment opportunities in India in future and is believed to be one of the major contributors to the Indian economy. As the growth of this industry is driven by the staff and their approach towards customers, it is imperative that the industry hire skilled and quality manpower resources capable of maintaining good rapport with the customers. This is because the customer's revisit and recommendation to prospects to visit the store mainly depends on the staff's interaction with the customer, apart from the other factors. This necessitates the need to understand aesthetic labour practices in retail sector and the contribution of HR Practices towards bringing, developing, maintaining and governing these aesthetic labour skills among the store employees to provide delightful experience for the customers by means of their appealing look and approach ability. Based on the study, a model was developed linking Aesthetic Labour with the various HR Practices to foster business.

Keywords: Retail industry, Aesthetic Labour, HR practices, delighted Customers.

\section{INTRODUCTION}

In interactive service work environment like retail, employees' especially frontline staffs interact with the customers directly, as a result this necessitates the staff to look presentable to the customers in an appealing manner and this forms the background of the study on Aesthetic labour. The term Aesthetics describes the way in which the employees carry, present and embody themselves in front of the customers. Every staff of the store individually represents the brand image of the organization, so it is necessary that they appear neat and presentable. Basically they must "look good and sound right" (Warhurst, C. and Nickson, D., 2001). Warhurst \& Nickson (2007) described Aesthetic labour as the employment of workers with desired physical features and temperaments appealing to the customers in course of their interaction with them. With this labour, employers intentionally use the required attributes and develop the capabilities of employees as a source of competitive advantage to delight the customers and thereby enhance their interest in making repeated visits to avail service from staff. It is found that some of the characteristics like appealing appearance, personal hygiene, body languages, social etiquettes, grooming etc., are to some extent possessed by employees at the point of entry of employment itself. However the employers channelize some of these characteristics of the individual workers desired for service encounter with the customers in the right direction, develop and commercialize these physical features and temperaments to gain competitive advantage. Aesthetic labour practices can be instilled and institutionalized in the organization through processes and practices right from recruitment and selection stage itself. Further, training, monitoring, disciplining and rewarding impressively to remodel the employees with required "skills" intends to 
produce desired "style" of service that sensitizes the customers. In other words, employee's Aesthetic attributes are appropriated, transformed and then managed by employers for commercial benefit (or at least employers attempt to do so).

Commercial benefit arises when organizations groom their employees to exhibit aesthetic skills to enhance productivity. Aesthetic skills held by the staff contribute towards upholding the corporate image held by the stores and attaining competitive advantage, further, they attract aspirational shoppers to visit the stores and leave a mark in their minds. Williams and Connell (2010) go further, stating that: Aesthetic labour includes a worker's manner, style, accent, voice, and attractiveness. Employees at these stores must embody particular styles of standing, speaking, and walking. "Looking good" and "sounding right" are their jobs' primary requirements.

Aesthetic labour practices is now slowly gaining impetus in certain service oriented sectors like retail, banks, hospitality, boutique hotels etc. The study mainly focuses on understanding the customer perception towards Aesthetic labour, the employer's expectations from the employees with respect to Aesthetic labour and employees comfort level to follow Aesthetic labour practices. The result of this study will help the hypermarkets in managing Aesthetic labour effectively.

\section{LITERATURE REVIEW}

In recent years many studies have been carried out on Aesthetic labour across the world for instance, Chris Warhurst and Dennis Nickson(2004) have attempted to study the employee's experience of Aesthetic Labour in Retail and Hospitality. He critically examined the employment of students in retail and various skills they bring along with them which helps to create competitive advantage. These would help them to easily align themselves with the aesthetic labour requirement of the specific sector.

Lynne Pettinger in the work "Gendered work meets Gendered goods: Selling and service in clothing retail" (2005) has tried to understand how gendering of tasks will affect the employees and discussed about how gender plays a role in retail occupation, shops and activities, tasks of each component combine to form the Aesthetic labour demand. Lynne also stresses on the point that attributes of the workers in terms of gender is important in stratifying stores and promoting the brand.

In the study conducted by Joanne Entwistle and Elizabeth Wissinger (2006), it is shown the workers in service industry need to be "always on" to perform better at work. Further the authors add that there are fluctuating aesthetic trends which workers have to address.

Malay Biswas has applied CHAID algorithm in his work "Aesthetic labour in India: locating and mapping the mind of the practitioners" (2009). Using this algorithm the researcher substantiated that in India, service sector gives importance to Aesthetic skills of employees. The author also felt that Aesthetic skills need to be part of curriculum of school and college as majority of future generation will be employed in this sector and there is immediate need for Aesthetic skills, therefore changes have to be bought into the syllabus of educational institutes and a dedicated program can be introduced to train the students.

Richard Hall and Diane Van Den Broek(2012) argued what should constitute "looking good and sounding right" in retail, will largely vary based on strategy, location, market and character of the store and brand. They have also highlighted employer's preferences of the labour demand for a particular look and style. Their analysis showed the ways in which Aesthetic labour can be mobilized, transformed and commoditized in addition to adding value to the workers.

Most of the studies conducted on Aesthetic labour by the researchers were confined to private sector but in the work conducted by Dorte Boesby Dahl (2013) it is evident that traces of Aesthetic labour can be seen even in public sector( non-commercial organisation). The author shows the balance between low-status authority works with citizen-consumer's desire to have pleasant service encounters.

Very few studies have been undertaken on Aesthetic Labour in Indian context, specifically retail sector.

\subsection{Gap identified from the previous studies:}

Previous studies on Aesthetic labour covered most of the Aesthetic labour aspects like dressing sense and style, make up, voice and accent but few other nonverbal forms of communication which is essential for 
retail sector were not considered. The earlier studies did not focus on those aspects likes slouching, kinesics, Proxemics and courteousness in addition to the other nonverbal forms covered. The body language like Slouchingi.e., maintaining upright posture in store is important as it projects the confidence level of the employees. Kinesics which indicates body movements are significant as they convey few things indirectly to the Customers like interest, disinterest etc. Courteousness of the employees is also important as customers would prefer those employees who are approachable. Proxemics indicates the space that should be maintained with the customer while addressing him so that he is comfortable. All the above aspects are very important to maintain Aesthetic labour in Organization. The study therefore aims at understanding all the aspects that contribute to the Aesthetic labour and how it can be institutionalised in the Organisation by means of HR practices like recruitment, selection, training, mentoring, rewards and recognition as it was found to be one of the factors that contribute to the bottom line in the retail sector.

\section{NEED/IMPORTANCE OF THE STUDY}

Despite the various study conducted on Aesthetic labour across the world, service industry in India lacks the connect between the HR practices and Aesthetic labour. In Indian context HR practices like recruitment, selection, training, mentoring, rewards/recognition need to be related with Aesthetic skills to increase the productivity of the employees .With the increase in growth of the service industry providing employment opportunities for many, the need of the hour is not just to provide manpower but quality manpower who have knowledge of tactfully handling their customers with their interpersonal skills and pleasant appearance and helping in improving the bottom line of the company.

\section{STATEMENT OF PROBLEM}

With the effect of liberalization, privatization, globalization and changes made in FDI in retail industry, Indian retail industry is facing a huge threat from foreign players. It therefore becomes very important for organisations to play it safe and sound in the market to meet the ever changing needs of their customers. To be in par with its competitors it needs to provide extraordinary services to its present as well as its potential customers. By extraordinary services we not only mean quality products and store ambience but it also includes making customers feel pleasurable at the store, the way they handle customers, this can be achieved by Aesthetic Labour. Further, more Indians are getting exposed to foreign life style due to overseas assignment or as tourists hence they expect similar kind of service in India.

\section{RESEARCH OBJECTIVES}

The primary objective of the study is to manage Aesthetic labour through HR practices at Hypermarkets in Indian Retail Sector. To realise the above objective, the perception of customers, management and employers towards aesthetic labour is studied; inputs are given to redesign the HR Processes and Practices to enhance aesthetic labour and also suggestions are given to improve the bottom lines through Aesthetic labour

\section{METHODOLOGY}

The research is descriptive in nature, as the study describes what exists and helped in uncovering new facts. Both Secondary as well as primary data is used in the study. Secondary data is collected from journals, articles etc. Primary data is collected through questionnaire, interview and observation method.ntil Questionnaire was administered to customers and employees of retail stores. Structured interview method was conducted to collect data from HR Personnel to link Aesthetic labour with H R Processes. Interview was conducted with staff and customers as well, to know their views. The sample size of the study is 250 customers and 100 frontline retail staff of hypermarkets. The sampling technique used in the study is convenience sampling technique. The questionnaire was pretested on 25 customers to check for the reliability (internal consistency) and validity. The reliability coefficient (alpha) was found to be 0.05 i.e., the reliability is quite high. The questionnaire was administered to every customer who entered the hypermarket. Another Questionnaire was prepared to check the comfort level of the store staff towards exhibiting aesthetic labour in Organization. The responses were collected from frontline staff of 4 different hypermarkets and then compiled. 25 staff from each store was selected based on convenience and questionnaire was administered to collect their responses.

The statistical tool used in the study is Friedman's two-way analysis of variance by ranks. Both descriptive statistics like percentage method and inferential statistics like Friedman's Two-Way 
analysis was used to find out variance by ranks given by:

$$
H=\frac{12}{N k(k+1)} \sum_{j=1}^{k} R_{j}{ }^{2}-3 N(k+1) \sim \chi_{\alpha}{ }^{2} \text { at }(k-1) \text { deg rees of freedom }
$$

Where,

$\mathrm{N}$ is the number of observations in each category.

$\mathrm{k}$ is the number of categories.

$R_{j}$ is the rank sum for the $\mathrm{j}^{\text {th }}$ category.

Friedman test is a non- parametric test that is used to detect the differences in treatments between multiple test attempts. This tool was used as the group is random sample from the population and the variables are measured on ordinal scale.

Friedman's two way analysis of variance was used to find out if there is significant difference in opinion of the customers towards Aesthetics of the frontline retail staff of hypermarket with respect to appearance, job knowledge and grooming standards.

\section{HYPOTHESES}

In the previous studies (Richard hall and Diane van den Broek, 2012) carried out, the elements which were considered in the study included personal hygiene, Grooming, jewellery, visible tattoo, age weight and height. In the research conducted by Chris Warhurst et.al (2004), issues related to training attended by employees were also considered, the types of training undertaken by employees according to the authors are product knowledge, company system and equipment's, social and interpersonal skills, self-presentation etc.

Hypothesis are formulated to understand the viewpoints of customers and staff of retail stores with respect to components which make up Aesthetic labour like appearance, grooming standards, job knowledge. These components are integral for the frontline staff as they carry the brand image of the organisation when they connect with the customers. Job knowledge is unduly important as it is an asset of immense value which the staff ought to possess.

The following hypotheses were formulated and tested: $H_{0} A$ : There is no significant difference in responses of the customers towards frontline retail staff's appearance.

$H_{1} A$ : There is significant difference in responses of the customers towards frontline retail staff's appearance.

$H_{0} B$ : There is no significant difference in the responses of customers towards aspects indicating the

appearance of male staff such that they have short hair and come cleanly shaved.

$H_{1} B$ : There is significant difference in the responses of customers towards aspects indicating the appearance of male staff such that they have short hair and come cleanly shaved.

$H_{0} \mathrm{C}$ : There is no significant difference in the responses of customers towards aspects indicating appearance of women staff such as makeup and well long tied hair.

$H_{l} C$ : There is significant difference in the responses of customers towards aspects indicating appearance of women staff such as makeup and well long tied hair.

$H_{0} D$ : There is no significant difference in the opinion of customers towards the grooming aspects such trimming nails and wearing minimal jewellery for frontline staff of retail stores.

$H_{0} D$ : There is significant difference in the opinion of customers towards the grooming aspects such trimming nails and wearing minimal jewellery for frontline staff of retail stores.

$H_{0} E$ : There is no significant difference in the opinion of customers towards job knowledge of frontline staff of retail stores.

$H_{0} E$ : There is significant difference in the opinion of customers towards job knowledge of frontline staff of retail stores.

$H_{0} F$ : There is no significant difference in the opinion of customers towards attributes required for frontline staff in retail stores.

$H_{1} F$ : There is significant difference in the opinion of customers towards attributes required for frontline staff in retail stores.

$H_{0} G$ : There is no significant difference in the responses of frontline retail staff towards their attributes

$H_{l} G$ : There is significant difference in the responses of frontline retail staff towards their attributes. 
International Journal of Trend in Scientific Research and Development (IJTSRD) ISSN: 2456-6470

8. RESULTS\& DISCUSSION

8.1 RESPONSE FROM 250 CUSTOMERS WHO VISITED HYPERMARKETS:

\begin{tabular}{|c|c|c|c|}
\hline \multirow{2}{*}{ VARIABLES } & CATEGORY & RESPONSE & $\%$ \\
\hline \multirow{2}{*}{ Gender } & Male & 112 & 44.8 \\
\cline { 2 - 4 } & Female & 138 & 55.2 \\
\hline
\end{tabular}

\section{CUSTOMER'S OPINION ON AESTHETIC LABOUR ATTRIBUTES EXPECTED IN FRONT LINE STAFF IN RETAIL SECTOR IN ORDER TO MAKE THEIR SHOPPING EXPERIENCE VERY PLEASANT}

\begin{tabular}{|c|c|c|c|}
\hline \multicolumn{4}{|c|}{ Appearance } \\
\hline AESTHETIC LABOUR ATTRIBUTES & OPINION & RESPONSE & $\%$ \\
\hline \multirow{3}{*}{ Put on uniform while at work } & To a great extent & 161 & 64.4 \\
\hline & Somewhat & 64 & 25.6 \\
\hline & c Not at all & 25 & 10 \\
\hline \multirow{3}{*}{ Display identity ca } & To a great extent & 144 & 57.6 \\
\hline & Somewhat & 86 & 34.4 \\
\hline & Not at all & Q & 8 \\
\hline \multirow{3}{*}{ Feature with clean shoes } & To a great extent & 123 & 49.2 \\
\hline & Somewhat & 190 & 36 \\
\hline & Not at all & 37 & 14.8 \\
\hline \multirow{3}{*}{ Consideration of staff's age during hiring } & To a great extent & 50 & 20 \\
\hline & ese Somewhat d & 127 & 50.8 \\
\hline & evel Not at all & 73 & 29.2 \\
\hline \multirow{3}{*}{$\begin{array}{l}\text { Consideration of height of the staff while } \\
\text { hiring }\end{array}$} & To a great extent & 28 & 11.2 \\
\hline & SN: 2 Somewhat 0 & 85 & 34 \\
\hline & Not at all & 137 & 54.8 \\
\hline
\end{tabular}

For Men

\begin{tabular}{|c|c|c|c|}
\hline AESTHETIC LABOUR A TTRIBUTES & OPINION & RESPONSE & $\%$ \\
\hline \multirow{4}{*}{ Should have short hair } & Strongly agree & 47 & 18.8 \\
\cline { 2 - 4 } & Agree & 86 & 34.4 \\
\cline { 2 - 4 } & Neutral & 70 & 28 \\
\cline { 2 - 4 } & Disagree & 32 & 12.8 \\
\cline { 2 - 4 } & Strongly disagree & 15 & 21.2 \\
\hline \multirow{3}{*}{ Have to be cleanly shaven } & Strongly agree & 53 & 37.2 \\
\cline { 2 - 4 } & Agree & 93 & 23.6 \\
\cline { 2 - 4 } & Neutral & 59 & 14 \\
\cline { 2 - 4 } & Disagree & 35 & 4 \\
\cline { 2 - 4 } & Strongly disagree & 10 & 6 \\
\hline
\end{tabular}


International Journal of Trend in Scientific Research and Development (IJTSRD) ISSN: 2456-6470

\begin{tabular}{|c|c|c|c|}
\hline AESTHETIC LA BOUR A TTRIBUTES & OPINION & RESPONSE & $\%$ \\
\hline \multirow{3}{*}{ Should wear light make up } & Strongly agree & 82 & 32.8 \\
\cline { 2 - 4 } & Agree & 79 & 31.6 \\
\cline { 2 - 4 } & Neutral & 63 & 23.2 \\
\cline { 2 - 4 } & Disagree & 16 & 6.4 \\
\cline { 2 - 4 } & Strongly disagree & 10 & 18.4 \\
\hline \multirow{3}{*}{ Should tie long hair } & Strongly agree & 46 & 19.2 \\
\cline { 2 - 4 } & Agree & 48 & 36 \\
\cline { 2 - 4 } & Neutral & 90 & 15.6 \\
\cline { 2 - 4 } & Disagree & 39 & 10.8 \\
\cline { 2 - 4 } & Strongly disagree & 27 & 4 \\
\cline { 2 - 4 }
\end{tabular}

\begin{tabular}{|c|c|c|c|}
\hline AESTHETIC LABOUR ATTRIBUTES & OPINION & RESPONSE & $\%$ \\
\hline \multirow{5}{*}{ Trim nails regularly } & Strongly agree & 75 & 30 \\
\hline & Agree & 66 & 26.4 \\
\hline & Neutral & $\begin{array}{r}79 \\
\end{array}$ & 31.6 \\
\hline & Disagree & 18 & 7.2 \\
\hline & Strongly disagree & 12 & 4.8 \\
\hline \multirow[t]{5}{*}{ Wear minimal Jewellery } & "En Strongly agree & C 56 & 22.4 \\
\hline & Agree and & 60 & 24 \\
\hline & Neutral & 80 & 32 \\
\hline & Disagree & 28 & 11.2 \\
\hline & Strongly disagree & 26 & 10.4 \\
\hline
\end{tabular}

\section{Presenting Self}

\begin{tabular}{|c|c|c|c|}
\hline AESTHETIC LABOUR ATTRIBUTES & OPINION & RESPONSE & $\%$ \\
\hline \multirow{2}{*}{ Maintain body Proximity with Customers } & Yes & 182 & 72.8 \\
\cline { 2 - 4 } & No & 68 & 27.2 \\
\hline \multirow{4}{*}{$\begin{array}{c}\text { Response of customer towards Staff } \\
\text { approaching them with bad body Odour }\end{array}$} & Definitely yes & 14 & 5.6 \\
\cline { 2 - 4 } & Probably yes & 42 & 16.8 \\
\cline { 2 - 4 } & Neutral & 48 & 19.2 \\
\cline { 2 - 4 } & Probably not & 47 & 39.6 \\
\hline \multirow{3}{*}{$\begin{array}{c}\text { Customers getting delighted with staff's } \\
\text { accent }\end{array}$} & Definitely Not & 99 & 4 \\
\cline { 2 - 4 } & To a great extent & 100 & 44 \\
\cline { 2 - 4 } & Somewhat & 110 & 16 \\
\hline
\end{tabular}


International Journal of Trend in Scientific Research and Development (IJTSRD) ISSN: 2456-6470

\begin{tabular}{|c|c|c|c|}
\hline AESTHETIC LABOUR ATTRIBUTES & OPINION & RESPONSE & $\%$ \\
\hline \multirow{2}{*}{$\begin{array}{c}\text { Perception of the customers as Casual } \\
\text { approach towards the Staff putting hand in } \\
\text { their Pocket }\end{array}$} & 'Yes & 107 & 42.8 \\
\hline & No & 143 & 57.2 \\
\hline \multirow{3}{*}{$\begin{array}{l}\text { Response of customer towards importance } \\
\text { of Staff's upright posture on Floor }\end{array}$} & Very important & 80 & 32 \\
\hline & Moderately important & 129 & 51.6 \\
\hline & Not at all important & 41 & 16.4 \\
\hline \multirow{3}{*}{$\begin{array}{l}\text { Response of customers towards their } \\
\text { shopping experience turning pleasurable if } \\
\text { greeted by the staff with a Smile }\end{array}$} & To a great extent & 136 & 54.4 \\
\hline & Somewhat & 90 & 36 \\
\hline & Not at all & 24 & 9.6 \\
\hline \multirow{3}{*}{$\begin{array}{l}\text { Response of the customers towards Change } \\
\text { in Perception of Store when staff have } \\
\text { personal talk while they are shopping }\end{array}$} & To a great extent & 47 & 18.8 \\
\hline & Somewhat & 135 & 54 \\
\hline & Not at all & 68 & 27.2 \\
\hline \multirow{5}{*}{$\begin{array}{l}\text { Response of customers towards whether } \\
\text { there is significance influence on their } \\
\text { shopping experience if the store staff is } \\
\text { Courteousness }\end{array}$} & Extremely significant & 67 & 26.8 \\
\hline & Significant & 131 & 52.4 \\
\hline & Neutral & 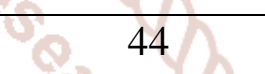 & 17.6 \\
\hline & Slightly Significant & & 3.2 \\
\hline & Insignificant & 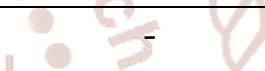 & - \\
\hline
\end{tabular}

Job knowledge

\begin{tabular}{|c|c|c|c|}
\hline AESTHETIC LABOUR ATTRIBUTES & OPINION & RESPONSE & $\%$ \\
\hline \multirow{5}{*}{$\begin{array}{l}\text { Staff's knowledge of items present in the } \\
\text { store }\end{array}$} & eVery important & 168 & 67.2 \\
\hline & Important & 55 & 22 \\
\hline & Neutral & & 5.6 \\
\hline & Slightly important & 5 & 2 \\
\hline & not important & & 3.2 \\
\hline \multirow{5}{*}{ Readiness in providing information to you } & Very important & 137 & 54.8 \\
\hline & Impo & 82 & 32.8 \\
\hline & Neutral & 17 & 6.8 \\
\hline & Slightly important & 7 & 2.8 \\
\hline & not important & 7 & 2.8 \\
\hline \multirow{5}{*}{$\begin{array}{l}\text { Openness to provide post purchase } \\
\text { assistance }\end{array}$} & Very important & 93 & 37.2 \\
\hline & Important & 95 & 38 \\
\hline & Neutral & 49 & 19.6 \\
\hline & Slightly important & 10 & 4 \\
\hline & not important & 3 & 1.2 \\
\hline
\end{tabular}


International Journal of Trend in Scientific Research and Development (IJTSRD) ISSN: 2456-6470

\begin{tabular}{|c|c|c|c|}
\hline AESTHETIC LABOUR ATTRIBUTES & OPINION & RESPONSE & $\%$ \\
\hline \multirow{5}{*}{$\begin{array}{l}\text { Enthusiastic to give awareness about the } \\
\text { product }\end{array}$} & Very important & 106 & 42.4 \\
\hline & Important & 107 & 42.8 \\
\hline & Neutral & 29 & 11.6 \\
\hline & Slightly important & 7 & 2.8 \\
\hline & not important & 1 & 0.4 \\
\hline \multirow{5}{*}{$\begin{array}{c}\text { Spontaneous in assisting you till the } \\
\text { parking lot }\end{array}$} & Very important & 56 & 22.4 \\
\hline & Important & 60 & 24 \\
\hline & Neutral & 85 & 34 \\
\hline & Slightly important & 24 & 9.6 \\
\hline & not important & 25 & 10 \\
\hline
\end{tabular}

\section{Staff's attributes}

\begin{tabular}{|c|c|c|c|}
\hline AESTHETIC LABOUR ATTRIBUTES & OPINION & RESPONSE & $\%$ \\
\hline & Very important & 126 & 50.4 \\
\hline & Important & 98 & 39.2 \\
\hline & Neutral & 19 & 7.6 \\
\hline & Slightly important & 6 & 2.4 \\
\hline Personal Hygiene & not important & 1 & 0.4 \\
\hline & Very important & 152 & 60.8 \\
\hline & ese Important & 69 & 27.6 \\
\hline & deve Neutral ent & 24 & 9.6 \\
\hline & Slightly important & 4 & 1.6 \\
\hline Job knowl & SN not important 0 & 1 & 0.4 \\
\hline & Very important & 107 & 42.8 \\
\hline & Important & 96 & 38.4 \\
\hline & Neutral & 40 & 16 \\
\hline & Slightly important & 6 & 2.4 \\
\hline Presentability & not important & 1 & 0.4 \\
\hline \multirow{5}{*}{ Courteousness } & Very important & 108 & 43.2 \\
\hline & Important & 84 & 33.6 \\
\hline & Neutral & 49 & 19.6 \\
\hline & Slightly important & 6 & 2.4 \\
\hline & not important & 3 & 1.2 \\
\hline
\end{tabular}

The study covers exhaustive aesthetic aspects like body proximity, slouching, gestures, job knowledge which along with grooming and presentation skills significantly add to the image of the store, as customers will have a very pleasant shopping experience.
The customers considered for the study included $45 \%$ male and $55 \%$ female. From the variables considered for the study related to appearance, it is understood that customers would want the frontline retail staff to be in uniform and identity card as they can differentiate them from other customers. Staff 
wearing clean shoes makes them feel good. But age of the staff doesn't matter much as long as they are sensible in their interaction with the customers. Height of the staff doesn't matter much to them at all. Customers would be fine with women with light makeup and hair tied up. They would look like to see both men and women in the store with neatly trimmed nails and male staff, with short hair, but it is not very important for them.

With respect to the parameters considered for an appealing presentation by the staff, the customers felt maintaining body proximity and upright is very important which itself will keep at bay their body odour, accent does not matter much to them and they don't bother about their casual approach like putting hands in the pocket.

However they felt having Job Knowledge is very important which involves knowledge of items, readiness to provide information, enthusiastic to help the customer from the time they come into the retail store till the parking lot and offer them post purchase assistance.

The main aesthetic attributes that one should look for in a prospective frontline staff include Personal hygiene, Job knowledge, Present ability and Courteousness in addition to basic qualification required.

\section{HYPOTHESES TESTING USING FRIEDMAN'S TWO WAY ANALYSIS OF VARIANCE TO UNDERSTAND THE DIFFERENCE IN RESPONSE OF CUSTOMERS TOWARDS AESTHETIC LABOUR PRACTICES FOLLOWED IN INDIAN RETAIL SECTOR:}

$\mathrm{H}_{0} \mathrm{~A}$ : There is no significant difference in responses of the customers towards frontline retail staff's appearance.

$\mathrm{H}_{1} \mathrm{~A}$ : There is significant difference in responses of the customers towards frontline retail staff's appearance.

\begin{tabular}{|c|c|c|c|c|c|}
\hline \multirow[t]{2}{*}{ Appearance } & \multicolumn{3}{|c|}{ Level of response } & \multirow{2}{*}{$\begin{array}{c}\text { Significance of } \\
\text { Chi-square } \\
\text { value }\end{array}$} & \multirow{2}{*}{$\begin{array}{l}\text { Critical value of } \\
\text { Chi square }\end{array}$} \\
\hline & $\begin{array}{l}\text { To a great } \\
\text { extent }\end{array}$ & Somewhat & Not at all & & \\
\hline $\begin{array}{l}\text { Put on uniform while at } \\
\text { work }\end{array}$ & 161 & -64 & 25 & & \\
\hline Display identity card & 144 & 856 & 20 & & \\
\hline Feature with clean shoes & 123 & 90 & & $0^{\mathrm{NS}}$ & 5.9910 \\
\hline $\begin{array}{c}\text { Consideration of staff's } \\
\text { age during hiring }\end{array}$ & 50 & & 2 & & \\
\hline $\begin{array}{l}\text { Consideration of height of } \\
\text { the staff while hiring }\end{array}$ & & & 137 & & \\
\hline
\end{tabular}

NS Not significant

Inference: There is no significant difference in responses of customers towards the extent of overall appearance of the staff in Frontline Retail stores. Therefore null hypothesis $\mathrm{H}_{0}$ Ais accepted.

$H_{0} B$ : There is no significant difference in the responses of customers towards aspects indicating the appearance of male staff such that they have short hair and come cleanly shaved.

$H_{1} B$ : There is significant difference in the responses of customers towards aspects indicating the appearance of male staff such that they have short hair and come cleanly shaved. 
International Journal of Trend in Scientific Research and Development (IJTSRD) ISSN: 2456-6470

\begin{tabular}{|c|c|c|c|c|c|c|c|}
\hline \multirow[t]{2}{*}{ Appearance } & \multicolumn{5}{|c|}{ Level of response } & \multirow{2}{*}{$\begin{array}{c}\text { Significance } \\
\text { of Chi- } \\
\text { square value }\end{array}$} & \multirow{2}{*}{$\begin{array}{l}\text { Critical value of } \\
\text { Chi- square }\end{array}$} \\
\hline & $\begin{array}{c}\text { Strongly } \\
\text { agree }\end{array}$ & Agree & Neutral & Disagree & $\begin{array}{l}\text { Strongly } \\
\text { disagree }\end{array}$ & & \\
\hline $\begin{array}{c}\text { Should have } \\
\text { short hair }\end{array}$ & 47 & 86 & 70 & 32 & 15 & \multirow[t]{2}{*}{$4.0000^{\mathrm{NS}}$} & \multirow[t]{2}{*}{9.4880} \\
\hline $\begin{array}{c}\text { Have to be } \\
\text { cleanly } \\
\text { shaven }\end{array}$ & 53 & 93 & 59 & 35 & 10 & & \\
\hline
\end{tabular}

NS Not significant

Inference: There is no significant difference in the responses of customers towards aspects indicating the appearance of male staff in Frontline Retail stores. Therefore null hypothesis $\mathrm{H}_{0} B$ Bis accepted.

$H_{0} \mathrm{C}$ : There is no significant difference in the responses of customers towards aspects indicating appearance of women staff such as makeup and well tied hair.

$H_{l} C$ : There is significant difference in the responses of customers towards aspects indicating appearance of women staff such as makeup and well tied hair.

\begin{tabular}{|c|c|c|c|c|c|c|c|}
\hline \multirow[t]{2}{*}{ Appearance } & \multicolumn{5}{|c|}{ Level of response } & \multirow{2}{*}{$\begin{array}{c}\text { Significance } \\
\text { of Chi- } \\
\text { square value }\end{array}$} & \multirow{2}{*}{$\begin{array}{c}\text { Critical } \\
\text { Value of } \\
\text { Chi- } \\
\text { square }\end{array}$} \\
\hline & $\begin{array}{l}\text { Strongly } \\
\text { agree }\end{array}$ & Agree & Neutral & $\begin{array}{l}\text { Disag } \\
\text { ree }\end{array}$ & $\begin{array}{l}\text { Strongly } \\
\text { disagree }\end{array}$ & & \\
\hline $\begin{array}{l}\text { Should wear light } \\
\text { make up }\end{array}$ & 820 & 79 & 63 & 16 & 10 & 6.0000 & 9.4880 \\
\hline Should tie long hair & 46 & 48 & 90 tions & $39 \mathrm{OL}$ & 27 का & & \\
\hline
\end{tabular}

\section{NS Not significant}

Inference: There is no significant difference in the responses of customers towards aspects indicating appearance of women staff such as makeup and well long tied hair. Therefore null hypothesis $H_{0} C$ is accepted.

$H_{0} D$ : There is no significant difference in the opinion of customers towards the grooming aspects such trimming nails and wearing minimal jewellery for frontline staff of retail stores.

$H_{0} D$ : There is significant difference in the opinion of customers towards the grooming aspects such trimming nails and wearing minimal jewellery for frontline staff of retail stores.

\begin{tabular}{|c|l|l|l|l|l|l|}
\hline \multirow{2}{*}{ Appearance } & \multicolumn{4}{|c|}{ Level of response } & \multicolumn{2}{c|}{$\begin{array}{c}\text { Significance of } \\
\text { Chi-square value }\end{array}$} \\
\cline { 2 - 6 } & $\begin{array}{c}\text { Strongly } \\
\text { agree }\end{array}$ & A gree & Neutral & Disagree & $\begin{array}{c}\text { Strongly } \\
\text { disagree }\end{array}$ & \multirow{2}{*}{$7.6000^{\mathrm{NS}}$} \\
\hline Trim nails regularly & 75 & 66 & 79 & 18 & 12 & \\
\hline Wear minimal Jewelry & 56 & 60 & 80 & 28 & 26 & \\
\hline
\end{tabular}

NS Not significant

Inference: There is no significant difference in the responses of customers towards the grooming aspects such as trimming nails and wearing minimal jewellery for frontline staff of Retail store, so therefore null hypothesis $H_{0} D$ is accepted.

$H_{0} E$ : There is no significant difference in the opinion of customers towards job knowledge of frontline staff of retail stores.

$H_{0} E$ : There is significant difference in the opinion of customers towards job knowledge of frontline staff of retail stores. 
International Journal of Trend in Scientific Research and Development (IJTSRD) ISSN: 2456-6470

\begin{tabular}{|c|c|c|c|c|c|c|c|}
\hline \multirow{2}{*}{$\begin{array}{c}\text { Job } \\
\text { knowledge }\end{array}$} & \multicolumn{5}{|c|}{ Level of response } & \multirow{2}{*}{$\begin{array}{l}\text { Significance } \\
\text { of Chi- } \\
\text { square } \\
\text { value }\end{array}$} & \multirow{2}{*}{$\begin{array}{l}\text { Critical } \\
\text { value of } \\
\text { Chi } \\
\text { square }\end{array}$} \\
\hline & $\begin{array}{c}\text { Very } \\
\text { important }\end{array}$ & Important & Neutral & $\begin{array}{c}\text { Slightly } \\
\text { important }\end{array}$ & Not & & \\
\hline $\begin{array}{c}\text { Staff's } \\
\text { knowledge of } \\
\text { items present } \\
\text { in the store }\end{array}$ & 168 & 55 & 14 & 5 & 8 & \multirow{5}{*}{$16.1200 * *$} & \multirow{5}{*}{13.2770} \\
\hline $\begin{array}{l}\text { Readiness in } \\
\text { providing } \\
\text { information to } \\
\text { you }\end{array}$ & 137 & 82 & 17 & 7 & 7 & & \\
\hline $\begin{array}{l}\text { Openness to } \\
\text { provide post } \\
\text { purchase } \\
\text { assistance }\end{array}$ & 93 & 95 & 49 & 10 & 3 & & \\
\hline $\begin{array}{l}\text { Enthusiastic } \\
\text { to give } \\
\text { awareness } \\
\text { about the } \\
\text { product }\end{array}$ & 106 & & & & & & \\
\hline $\begin{array}{l}\text { Spontaneous } \\
\text { in assisting } \\
\text { you till the } \\
\text { parking lot }\end{array}$ & 30 & 60 & 85 & 24 & 25 & & \\
\hline
\end{tabular}

** Significant at $1 \%$ level

Inference: There is significant difference in the responses of customers towards the extent of job knowledge among staff in Frontline Retail stores. Therefore null hypothesis $H_{0} E$ is rejected.

$H_{0} F$ : There is no significant difference in the opinion of customers towards attributes required for frontline staff in retail stores.

$H_{1} F$ : There is significant difference in the opinion of customers towards attributes required for frontline staff in retail

stores.

\begin{tabular}{|c|c|c|c|c|c|c|c|}
\hline \multirow{2}{*}{$\begin{array}{c}\text { Staff's } \\
\text { attributes }\end{array}$} & \multicolumn{5}{|c|}{ Level of response } & \multirow{2}{*}{$\begin{array}{l}\text { Significance } \\
\text { of Chi- } \\
\text { square } \\
\text { value }\end{array}$} & \multirow{2}{*}{$\begin{array}{c}\text { Critical } \\
\text { value of } \\
\text { Chi } \\
\text { square }\end{array}$} \\
\hline & $\begin{array}{c}\text { Very } \\
\text { important }\end{array}$ & Important & Neutral & $\begin{array}{l}\text { Slightly } \\
\text { important }\end{array}$ & $\begin{array}{c}\text { Not } \\
\text { important }\end{array}$ & & \\
\hline $\begin{array}{l}\text { Personal } \\
\text { Hygiene }\end{array}$ & 126 & 98 & 19 & 6 & 1 & \multirow{4}{*}{$16.0000 * *$} & \multirow{4}{*}{13.2770} \\
\hline Job knowledge & 152 & 69 & 24 & 4 & 1 & & \\
\hline $\begin{array}{c}\text { Self- } \\
\text { presentation }\end{array}$ & 107 & 96 & 40 & 6 & 1 & & \\
\hline Courteousness & 108 & 84 & 49 & 6 & 3 & & \\
\hline
\end{tabular}

Inference: There is significant difference in the responses of customers towards the extent of Staff's attributes in Frontline Retail stores, therefore null hypothesis $H_{0} F$ is rejected

Customer's felt that Aesthetic aspects like appearance, hygiene, self-presentation, job knowledge, body language play a major role in making their shopping experience pleasurable. 
International Journal of Trend in Scientific Research and Development (IJTSRD) ISSN: 2456-6470

8.2 RESPONSES OF 100 FRONTLINE RETAIL STAFF OF HYPERMARKETS:

\begin{tabular}{|c|c|c|c|}
\hline VARIABLES & CATEGORY & REPONSES & $\%$ \\
\hline \multirow[t]{2}{*}{ Gender } & Male & 41 & 41 \\
\hline & Female & 59 & 59 \\
\hline \multirow[t]{4}{*}{ Association with retail industry } & More than 1Month & 21 & 21 \\
\hline & More than 3 Months & 10 & 10 \\
\hline & More than 6 Months & 13 & 13 \\
\hline & More than 1 year & 56 & 56 \\
\hline \multirow[t]{3}{*}{ Recognition of company by their uniform } & To a great extent & 74 & 74 \\
\hline & Some what & 17 & 17 \\
\hline & Not at all & 9 & 9 \\
\hline \multirow[t]{3}{*}{ Comfortability with wearing uniform } & Comfortable to a great extent & 78 & 78 \\
\hline & Somewhat comfortable & 20 & 20 \\
\hline & Not at all comfortable & 2 & 2 \\
\hline \multirow{2}{*}{ Work without uniform for a day } & Yes & 82 & 82 \\
\hline & No & 18 & 18 \\
\hline \multirow{3}{*}{ Interruption in work by wearing ID card } & C1E To a great extent & 35 & 35 \\
\hline & Some what & 21 & 21 \\
\hline & Not at all & 44 & 44 \\
\hline Conveying information while maintaining & Easy to a great extent & 52 & 52 \\
\hline \multirow{2}{*}{ body proximity } & Somewhat easy & 38 & 38 \\
\hline & Not at all easy & 10 & 10 \\
\hline \multirow{2}{*}{ Store following best grooming standards } & 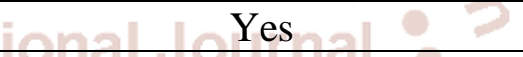 & 99 & 99 \\
\hline & No & 1 & 1 \\
\hline \multirow[t]{3}{*}{ Adaption to grooming practices } & in Easy to great extent & 73 & 73 \\
\hline & Somewhat easy & 24 & 24 \\
\hline & Notict at all easy & 3 & 3 \\
\hline \multirow{2}{*}{ Happiness in Maintaining upright posture } & alominges & 79 & 79 \\
\hline & No & 21 & 21 \\
\hline \multirow{3}{*}{ Maintaining personal hygiene } & Easy to maintain & 72 & 72 \\
\hline & Somewhat easy to maintain & 23 & 23 \\
\hline & Not easy to maintain & 5 & 5 \\
\hline \multirow[t]{3}{*}{ Maintaining Self-presentation } & Easy to maintain & 68 & 68 \\
\hline & Somewhat easy to maintain & 31 & 31 \\
\hline & Not easy to maintain & 1 & 1 \\
\hline \multirow[t]{3}{*}{ Maintaining politeness } & Easy to maintain & 62 & 62 \\
\hline & Somewhat easy to maintain & 29 & 29 \\
\hline & Not easy to maintain & 9 & 9 \\
\hline
\end{tabular}

In the study conducted by Chris Warhurst and team, we found that grooming, body language; soft skills are important features which a candidate should possess if he has to be successful in the retail sector. In this study, apart from the aesthetic features identified that is important in the Indian retail sector, an attempt was also made to find out if the frontline staffs are comfortable in adopting these practices and following the grooming standards of the company.

\section{HYPOTHESIS TESTING USING FRIEDMAN'S TWO WAY ANALYSIS OF VARIANCE TO FIND OUT THE DIFFERENCE IN OPINION AMONG FRONTLINE RETAIL STAFF TOWARDS AESTHETIC LABOUR PRACTICES FOLLOWED:}

$\mathrm{H}_{0} \mathrm{G}$ : There is no significant difference in the responses of frontline retail staff towards the given attributes $\mathrm{H}_{1} \mathrm{G}$ : There is significant difference in the responses of frontline retail staff towards the given attributes 
International Journal of Trend in Scientific Research and Development (IJTSRD) ISSN: 2456-6470

\begin{tabular}{|c|c|c|c|c|c|}
\hline \multirow[t]{2}{*}{ Staff's attributes } & \multicolumn{3}{|c|}{ Level of response } & \multirow{2}{*}{$\begin{array}{l}\text { Significance } \\
\text { of Chi- } \\
\text { square value }\end{array}$} & \multirow{2}{*}{$\begin{array}{c}\text { Critical } \\
\text { value of Chi } \\
\text { square }\end{array}$} \\
\hline & $\begin{array}{l}\text { Easy to } \\
\text { maintain }\end{array}$ & $\begin{array}{c}\text { Somewhat } \\
\text { easy to } \\
\text { maintain }\end{array}$ & $\begin{array}{c}\text { Not easy } \\
\text { to } \\
\text { maintain }\end{array}$ & & \\
\hline Personal Hygiene & 72 & 23 & 5 & \multirow{3}{*}{$6.0000^{*}$} & \multirow{3}{*}{5.9910} \\
\hline Self-presentation & 68 & 31 & 1 & & \\
\hline Politeness & 62 & 29 & 9 & & \\
\hline
\end{tabular}

Inference: There is significant difference in the responses of Frontline retail Staff towards their attributes, therefore null hypothesis $H_{0} G$ is rejected.

From the above hypotheses testing results, we can infer that with reference to the response towards aesthetic labour attributes followed by customers, there no significance difference in the opinions as stated in $\mathrm{H}_{0} \mathrm{~A}, \mathrm{H}_{0} \mathrm{~B}$, $\mathrm{H}_{0} \mathrm{C}, \mathrm{H}_{0} \mathrm{D}$ i.e.., the null hypothesis is accepted. However with respect to statements $\mathrm{H}_{0} \mathrm{E}, \mathrm{H}_{0} \mathrm{~F}, \mathrm{H}_{0} \mathrm{G}$, to check the difference in opinion among retail front line staff towards following aesthetic labour, the result showed that the null hypothesis has to be rejected, in other words the alternate hypothesis has to be accepted.

MODEL LINKING AESTHETIC LABOUR WITH HR PRACTICES TO ENHANCE PERFORMANCE

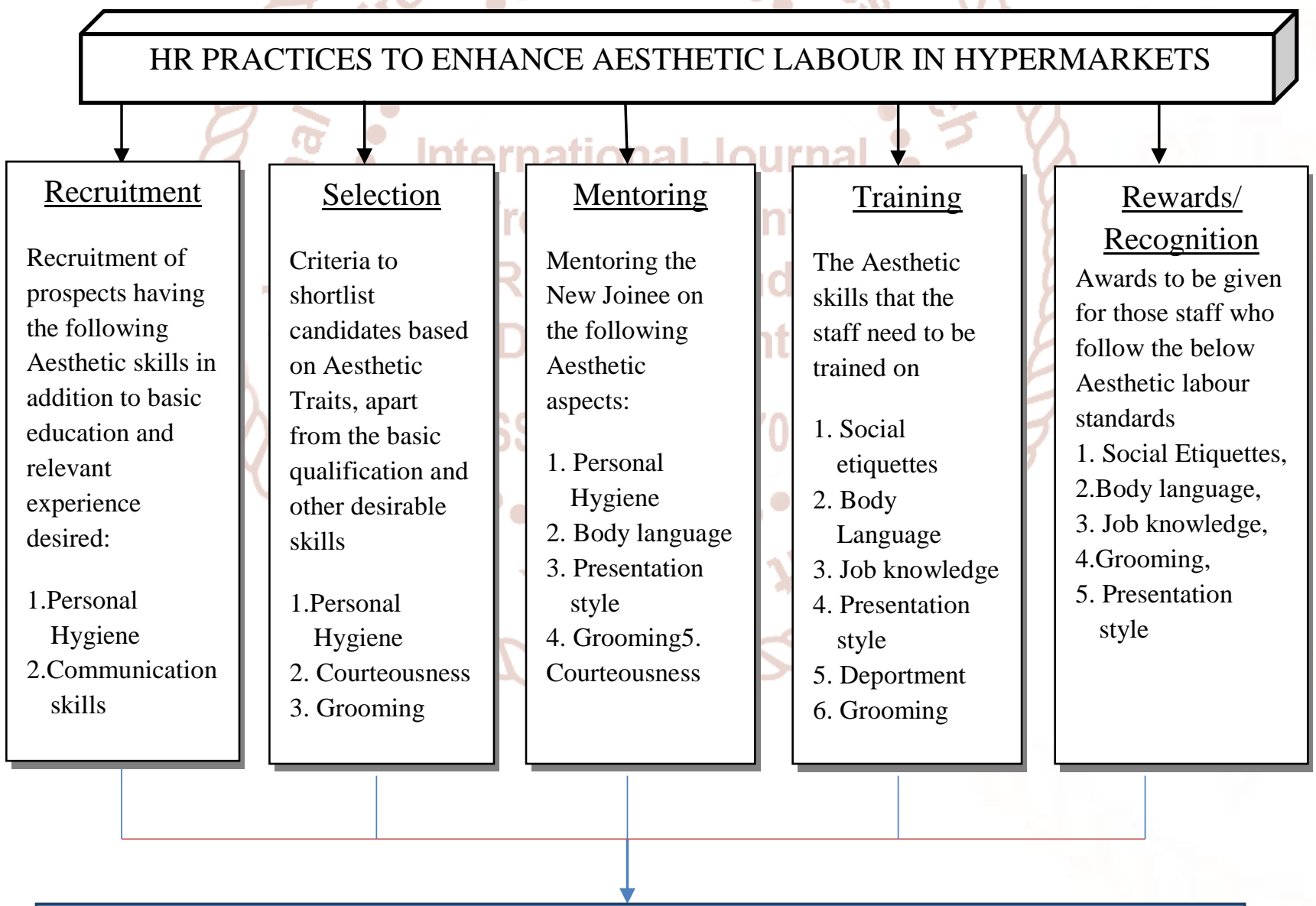

\section{ENHANCES INDIVIDUAL AS WELL AS ORGANIZATION'S PERFORMANCE IF INSTITUTIONALISED}

The above model indicates how Aesthetic labour practices can be institutionalised in the Organisation by embedding it in the HR practices like Recruitment, selection, mentoring, training, reward sand recognition to contribute the bottom line. The figure depicts the desirable Aesthetic attributes along with education, work experience etc., that needs to be predominantly looked upon and considered to an extent with respect to staff on the floor while 
performing their work. This gives them competitive edge over the others.

\section{Recruitment}

The Aesthetic parameters that need to be considered while recruiting a candidate for retail store (Hypermarket) as frontline staffs are Personal Hygiene and Communication skills in addition to the basic qualification to meet the job requirements. The employment advertisement should also specify the desirable Aesthetic traits for the position along with the basic qualifications so that they can choose from the pool of eligible applicants. Personal Hygiene can be considered as one of the main Aesthetic trait for store staff in retail sector. Personal Hygiene for men include wearing clean and neat dress without any stain, being cleanly shaven with short hair, nails clean and trimmed, with pleasant body odour. Personal Hygiene for women include wearing neat and clean dress, neatly tied hair, keeping nails clean and trimmed, taking measures to prevent bad body odour. The candidate also has to be in a position to communicate effectively and clearly with right kind of attitude.

\section{Selection}

Selecting a candidate from the pool of applicants is not an easy job especially for the position of store staff in the retail sector as this job necessitates interaction with the customers. Aesthetic attributes used to measure a candidate for frontline staff position in a retail store (Hypermarket) include Personal Hygiene, Courteousness, and Grooming. The employers of a retail store (hypermarket) need to review the prevailing grooming and personal hygiene of the candidate i.e., how well or to what extent the candidate is taking care of his personal hygiene that includes neatly combed hair, body, oral hygiene, dress code at the time of interview. Amidst selection process basic aspects of courteousness like good manners, showing respect towards others and being humble during the interaction should be given due consideration. Along with these traits, subsequently if the staffs are trained in social etiquettes after they are hired; it could enhance the Organisation's Performance.

\section{Mentoring:}

The Aesthetic aspects that need to be looked upon and covered while mentoring the frontline staff are Personal Hygiene, Body language, Presentation style, grooming and Courteousness. Body language in terms of maintaining upright postures on floor, their hand movements and gestures while interacting with customers, especially of opposite sex and also maintaining appropriate body proximity with the customers is very important. Personal hygiene like hair neatly trimmed and tied, maintaining pleasant body odour and keeping nails clean and trimmed cannot be ignored. The mentors should also guide the staff to be courteousness and nurture them to behave politely, exchange greetings, exhibit good manners and maintain the decorum at their workplace. The staff's adaptation of existing grooming standards of the organisation and their presentation contributes to the Organisation's performance.

\section{Training:}

Prior to providing training the management along with the trainer should make an attempt to find out the educational, family and professional (if any)background of the trainees, this is imperative because, if the staff have prior retail work experience or if the staff is not well educated to understand the importance of Aesthetics, training methodology can be reshaped accordingly. The training program should be designed in such a way that it covers areas like Social Etiquettes, Body Language, Job knowledge, Presentation style, Deportment, Grooming. Social etiquettes such as acknowledging the customers, avoiding personal talks with personal required to give the customers a pleasant shopping experience. The staffs need to have thorough job knowledge to convince and persuade the customers to buy the products. In order to achieve that, they should be enthusiastic and spontaneous to assist and give information about the items to the customers. Along with this, the staffs need to be trained on deportment which means the way they need to walk and stand in the store.

\section{Rewards/ Recognition:}

The Rewards/recognition is solely the motivating factor for staff. The quality of performance and productivity is directly linked to it. The rewards or recognition should be provided considering overall Aesthetic features of individual like Social Etiquettes, Body language, Job knowledge, Grooming, Presentation style etc.

\section{RECOMMENDATIONS/SUGGESTIONS}

In retail sector, it is very important for the management to understand that aesthetic labour practices followed by their staff has implications on 
improving their bottom lines as the customers revisit and recommend the prospective customers to the store if they have had a pleasurable shopping experience. Therefore the custom of greeting and wishing the customers to delight them must be strictly incorporated. Innovative rewards like giving away badges and posting pictures of well-groomed staff can motivate the staff to adhere to the grooming standards. The training given to the staff on aesthetics must be customised according to the job profile based on education, family background and prior work experience. Organisations should regularly survey ever changing needs of the customers from the staff so that organisation can meet the needs and live up to the expectations of the customers. Finally Aesthetic Labour needs to be institutionalized in the organisation at every level.

\section{CONCLUSION}

The study showed that customers are very particular about the Aesthetic skills of the staff interacting with them. They foresee the staff to be an assortment of various aesthetic labour skills, be it job knowledge or social decorum. Employers need to embed these aesthetic practices in their $\mathrm{HR}$ functions to institutionalise aesthetic skills in the organisation which would indeed have an impact on the organisational performance.

On the other hand, staffs employed in hypermarkets are flexible and resilient. They find it easy to adapt to the organisation's grooming practices, which proves that they are aware of the importance of their appearance in front of the customer.

\section{SCOPE OF FURTHER RESEARCH:}

The study attempts to find out the Aesthetic labour Practices in the retail sector that can enhance the bottom lines. Aesthetic labour is studied from the perspective of the customer, management and employees and appropriate practices are designed that gives a delightful experience for the customers upholding the benefits to Management and interest of employees alike in the retail sector. Aesthetic Labour Management Studies can be extended to other service sectors like hospitality, banking etc. Further studies could be carried out to find out the relationship between Aesthetic labour practices and performance of the Organisation. Comparative study between and urban and rural areas can also be conducted.

\section{REFERENCES}

1. Lynne Pettinger (2005), "Gendered work Meets Gendered Goods: Selling and Service in Clothing Retail, Gender, work and organization,'Vol.12, pp.461.

2. Malay Biswas (2009), "Aesthetic Labour in India: locating and mapping the mind of the practitioners-an application of CHAID algorithm," Journal of services research, Vol.9, pp. 81.

3. Chris Warhurst, Dennis Nickson and Eli Dutton., (2004), "The view from the frontline: student employees and Aesthetic Labour in Retail and Hospitality" Paper to the Work, Employment and society Conference, 1-3.

4. Richard Hall and Diane Van den Broek., (2012), "Aestheticizing retail Worker: Orientation of Aesthetic labour in Australian fashion retail," Economic and industrial democracy,33(1), pp.85.

5. Dorte Boesby Dahl, Nordic.,(2013), "Looking Neat on the Street. Aesthetic Labor in Public Parking Patrol," journal of working life studies, Vol.3,pp. 2.

6. Joanne Entwistle and Elizabeth Wissinger., (2006) "keeping up appearances: Aesthetic labour in the fashion modelling industries of London and New York," The Sociological Review, pp.54.

7. https://www.ibef.org/industry/retail-india.aspx, accessed on $2^{\text {nd }}$ August 2017. 